\title{
The Role of NSCDC in Crime Prevention in Nigeria: Conceptual and Emperical Analysis
}

\author{
Usman Suleiman Sarki, Mansur Ya'u \\ Department of Sociology, Federal University Dutse, Jigawa State, Nigeria
}

\begin{abstract}
Peace is necessary for the development of any society because no society can develop in the state of conflict and insecurity. Despite the fact that all society are characterized with crime, the need to prevent and control crime in the society has become necessary which lead to the establishment of both formal and informal by the society in order to control the menace of crime and help society achieved social order. The issue of safety of lives and property of the citizens in Nigeria is obviously increasing despite the presence of the formal law enforcement agencies such as the Nigerian police force. In an efforts to curtail the increase rate of crime in the country, the Constitution of the Federal Republic of Nigeria provide for the establishment of more security agencies such as the Nigerian Security and Civil Defence Corps (NSCDC) in order to prevent menace of crime in the society. Against this background, this paper empirically analyze the role of Nigerian Security and Civil Defence Corps (NSCDC) in preventing crime in Nigeria with a view assess its achievements and challenges so as to proffer more ways of enhancing its performance in crime prevention.
\end{abstract}

KEYWORDS: Analysis, Crime, Peace, Prevention, Role

\section{INTRODUCTION}

Crime is one of the major social problems bedeviling contemporary Nigerian society. The menace of crime is affecting not only economic development of Nigeria but also to tarnish the image of the country in the eyes of the international community. Crime is an intentional act that violates the provision of the criminal law. The increasing rate of so many crimes such as kidnapping, armed robbery, rape, pipeline vandalism etc. has resulted to the establishment of more security agencies in order to address these challenges confronting Nigerian society. Nigerian security and civil defense corps was established by the government in order to ensure protection of lives and properties and protect public property against vandalism as well as to assist other security agencies in crime prevention and control (NSCDC Act, 2003).

The problem of criminality and crime seem to be on the increase in the twenty-first century Nigeria, thus raising serious concerns about law and order in the society. The security and welfare of the people is the primary responsibility of government and every citizen is expected to assist law enforcement agencies in the maintenance of law and order and crime prevention and control in the society. Bernard and Olusegun (2013) state that "there is no society that is totally free from crime and criminality but the degree of its presence and occurrence varies from one society to the and this also depends on the mechanisms put in place to checkmate the trend and incidence. Each race or identity group in the world had and have, accepted and collective patterns and method of social control and conflict resolution". In an effort to prevent and control crime in the society, the constitution of the federal republic of Nigeria provide for the establishment of security agencies such as the Nigerian police force in order to prevent and control the menace of crime in the society, however, despite the efforts of the Government through Nigerian police force to protect lives and property of the citizens, the level of crime is increasing (Adebayo, 2006).
The various security challenges such as insurgency, kidnapping and pipeline vandalisation bedeviling Nigerian society resulted to the establishment of Nigerian Security and Civil Defense Corps in order to compliment the effort of other security agencies in crime detection, prevention and control. Despite the fact that, with establishment of Nigerian security and civil defense corps there is still raising wave of crime in the country, however, Nigerian security and civil defense corps is putting various measures and strategies in order to prevent and control criminal behavior in the society. Nigerian Security and Civil Defense Corps is a paramilitary agency of the government of the federal republic of Nigeria that was established to provide measures against threats and any attack or disaster. The major concern of NSCDC is to assist the Nigerian police force and other law enforcement agents in ensuring safety of lives and property in the country (Blessing, 2009).

\section{PROBLEM STATEMENT}

Peace is very necessary for the development of any society because no society can develop in the state of conflict and insecurity. Despite the fact that all societies are characterized with crime, the need to prevent and control crime in the society has become necessary which leads to the establishment of both formal and informal mechanism by the society in order to control the menace of crime and help society achieved social order. The issue of safety of lives and property of the citizens in Nigeria is becoming increasingly dubious despite the presence of the formal law enforcement agencies such as the Nigerian police force and NSCDC.

Seemingly, crime in Nigeria continues to persist even with the existence of several security agencies that were established by the Government to prevent and control crime in the society. The Nigerian Security and Civil Defense Corps (NSCDC) were established to complement the role and effort of Nigerian police and other security agencies in order to ensure safety of lives and property. The increasing rate of the activities of pipeline vandals, rapid increase of armed 
robbery, theft and vandalisation of Government property necessitated the establishment of NSCDC in order to join other security agencies in crime prevention and control. Nevertheless, the emergence of NSCDC did not stop the occurrence of crimes such as pipeline vandalisation, destruction of public property, and high rate of kidnapping among others (Eric and Oluwagbenga, 2017). Against this background, this study set to assess the role of NSCDC in crime prevention with a view to identify its strengths and weaknesses so as to proffer possible solutions that could ensure the effectiveness of the agency in crime prevention in Nigeria.

\section{LITERATURE REVIEW CONCEPT OF CRIME PREVENTION}

The rate of crime today in the society has become an issue of concern among scholars of criminology and other related disciplines the menace of crime undermines the social fabric by eroding the sense of safety and security. crimes is a threat to the economic, political and social security of a nation and a major factor associated with underdevelopment; because it discourages both local and foreign investment, reduce the quality of life and destroy human and social capital (Adebayo, 2013). As a result of the rapid implications of the menace of crime, the concept of crime prevention and control arise which aims at controlling, reducing and preventing crime in the society in order to ensure rapid economic growth and development and to help society to achieve social order.

Crime prevention has to do with the attempt made by the government and society and to reduce and deter crimes and criminals. It encompasses the effort to reduce crime, enforce laws and maintaining of social order in the society. According to the United Nation office on drugs and crimes (2004), crime prevention comprises strategies and measures that seek to reduce the risk of crime occurring, and their potential harmful effects on individual and society, including fear of crime by intervening to influence their multiple causes. Crime control on the other hand refers to the measures taken to reduce crime in the society. This implies that it has to do with both formal and informal strategies that are used to reduce the impact of crime in the society. For Clifford (1974), crime prevention refers to the measures by law enforcement agents or institutions to prevent the commission of crime or reduce to reduce it to the minimal level. Crime prevention is an intervention in the causes of crimes and disorderly event to reduce, prevent and control the risk of their resource and the potential seriousness of their consequences (Steven, 2010). This definition addresses both crime and its impact on individuals and society as well as the measures to combat the menace of crime. He went further to argues that crime prevention entails any action designed to reduce the level of crime and or perceived fear of crime.

Nigeria is among the developing countries of the world that is bedeviled with so many criminal activities such as corruption, armed robbery, theft, murder, kidnapping and so on. As a result of the rapid increase of criminal cases, the need for crime prevention became a necessity in order to safe guards, and protects citizens from fear of danger and harm (Adebayo, 2013). Crime prevention involves community, government as well as individuals as well as the activities of the criminal justice system. In essence, Adebayo (2013) argues that crime prevention encompasses the disruption of mechanisms which cause criminal events. Maguire, Morgan and Reiner (1997) posits that criminologists that have devised several ways of preventing crime in the society rest on three principles. These principles include:

1. Since crime consists of diverse behavior, we should not look for universality in techniques of prevention.

2. Because an action is a crime, this does not mean that best way to control it is through the police and courts. The behavior itself must be understood, to determine where change could best be brought about.

3. The scope of the criminal is morally problematic. A society in which more crime is prevented is not necessarily a more pleasant society. The burdens and restrictions imposed on people to prevent crime must be balanced against the harm caused by the crime prevented.

The definition of crime prevention differs depending on the discipline and the orientation of the scholars. Ekblom (nd) (as cited in Steven, 2010) posits that crime prevention has to do with the intervention in the causes of crimes and disorderly event to reduce the risk of their resource and or the potential seriousness of their consequences. This implies that crime prevention encompasses any action designed by the society or government to reduce the level of crime and or perceived threat or fear of crime.

According to Steven (2010), crime prevention can be categorized in to primary, secondary, and tertiary crime prevention and control. Primary crime prevention has to do with the identification of the conditions and opportunities that predisposed or precipitate criminals to commit crime. Accordingly, crime can be prevented through environmental design, and neighborhood watch among others. In secondary crime prevention, it involves the identification and prediction of potential offenders and seeks to intervene before the commission of a crime. Tertiary crime prevention on the other hand encompasses dealing with actual offenders and involves intervention in such a way that they will never commit crime. In other words, their behavior will be rehabilitated and reformed so as to become conforming members of the society.

\section{ROLES OF NSCDC IN CRIME PREVENTION}

Nigerian security and civil defense are playing vital roles in the prevention of crimes. According to NSCDC Act (2007), some of these roles include:

\section{CRIME DETECTION}

NSCDC as a security agency is charged with the responsibility for enforcing laws. Therefore, one of it critical role is the crime prevention and detection. Edge et al (nd) noted that the NSCDC shall be employed to strategically detect crimes in the society. Despite the fact that in many countries the responsibility of crime prevention is vested on the police but in this part of the world NSCDC are among the formal law enforcement agencies that carryout the role of crime prevention and detection in the country. Crime detection falls in to 3 categories i.e. the discovery of crime has been committed, the identification of suspects and collection of evidence for successful prosecution of the offenders. This role is usually carried out by the NSCDC through its criminal investigation department. 


\section{MAINTENANCE OF LAW AND ORDER}

Another role of NSCDC in crime prevention and control is the maintenance of law and order in the society. The Nigerian law gave the NSCDC mandates to forced people to obey laws and to avoid any act that will leads to violence or creates confusion among people. The government of the federal republic of Nigeria has vested the Nigerian security and civil defense corps with the responsibility and power to play the role of maintenance and order in the society.

\section{APPREHENSION OF OFFENDERS}

The Nigerian security and civil defense corps plays a role of arresting or apprehension of the suspected criminals. Despite the fact that majority of the Nigerian populace have the habit of taking a law at their hands without reporting a case to the NSCDC, police and other law enforcement agencies, it's only the formal law enforcement agency such as NSCDC that vested with the responsibility to arrest suspects and arraigned them before a court for prosecution

\section{PROTECTIONS OF LIVES AND PROPERTY}

Another primary role of the NSCDC is the protection of lives and properties of the people of the country. According to Dansabo (2014), NSCDC personnel are provided with weapons such as guns, ammunition, and military training in order to protect the lives and properties of the civilian population. Protection of lives and property is the major rationale behind the establishment of any law enforcement agency; NSCDC inclusive. The Nigerian security and civil defense corps are playing a greater role in crime prevention. As a result of the rapid increase of criminal activities, the corps was established by the government with the statutory functions of maintaining law and order and complementing the efforts of other security agencies in crime prevention and control. From the day of establishment to date, the Nigerian security and civil defense corps has play several roles in order to ensure effective crime prevention and control in the society. Adebayo (2013) is of the believed that providing NSCDC personnel with weapons such as guns and ammunitions, vehicles and strong communication gadget has also improve the role they played in crime prevention and control. He went further to argued that there is need to differentiate their role and that of Nigerian police in order to avoid inter agency rivalry and improve the roles they play in curtailing crimes and criminality in Nigeria and to ensure effective prevention of crimes.

Nigerian and Civil Defense Corps has succeeded in playing so many other roles ranging from arresting so many criminals and controlling many variety of criminal activities like shoplifting, kidnapping, armed robbery, and pipelines vandalism among others. The method of operation of the Nigerian Security and Civil Defense Corps has assisted the agency in playing it roles to control and prevent crimes. The NSCDC ACT of 2007 had vested the agency with the power to apprehend pipelines vandals, to take care of all the public and private property and to register, trained and supervised the activities of all private guards companies (Madaki, 2016). Also, Nigerian Civil Defense Corps are empowered to maintain 24 hours surveillance over infrastructures, sites and projects for the federal, state and local government (NSCDC amended ACT, 2007). The corps should assist to the maintenance of peace and order, and in the protection, rescuing of the civil population during the period of emergency. Recommend to the minister, the registration of private guard companies, from time to time respect the premises of private guard companies, their training facilities and approve same if it is up to standard. It is also part of their role to periodically organize seminars and work shop to the private guard companies in order to ensure effective crime prevention and control (Abolurin, 2008).

Other roles of NSCDC include search of premises and seizure of any materials suspected to have been used in vandalisation or suspected process of vandalisation, search of premises of any suspected illegal dealer of petroleum product or materials used by power holding company of Nigeria, postal services, Nigerian telecommunication or for any other public utility or infrastructure in an attempt to prevent crime in the country (Uzondu, 2012). Accordingly, Phenson (2014) stated that the role of NSCDC also include monitor, investigate and take every necessary step to forestall any act of terrorism and report same to appropriate federal security agencies; provide necessary warning for the civilian population from danger areas; provide and manage shelters of the civilians during period of emergency; assist in the decontamination and in the taking of precautionary measures during any period of emergency; carryout rescue operation and control volatile situation; assist in the provision of emergency medical services, including first aid during any period of emergency and detect and demarcate any danger area in to effectively prevent and control crimes in the country.

\section{METHODOLOGY}

The paper adopted a survey research design which involves the administration of structured questionnaires and an indepth interview with stake holders (i.e. community leaders and NSCDC personnel) in the study area. The paper is aimed at gathering information that will helps in assessing the role of NSCDC in crime prevention in Nigeria. Statistical Packages for Social Sciences (SPSS Version: 22) was used in analyzing the qualitative data while the qualitative data that were elicited through in-depth interview was coded manually and used to complement the quantitative data.

\section{RESULTS AND DISCUSSION}

ROLES OF NSCDC IN CRIME PREVENTION IN NIGERIA Table 1: Whether NSCDC play Role in Crime Prevention

\begin{tabular}{|c|c|c|}
\hline Responses & Frequency & Percentage \\
\hline Yes & 71 & 93.4 \\
\hline No & 5 & 6.6 \\
\hline Total & $\mathbf{7 6}$ & $\mathbf{1 0 0}$ \\
\hline
\end{tabular}

Source: Field work, 2018

Table 1 presents the respondent's views on whether NSCDC play a role in preventing crime. It revealed that $93.4 \%$ of the respondents stated that NSCDC play a role in crime prevention and control while the $6.6 \%$ of the respondents who are the minority did not. In essence, majority of the respondents were of the believed that NSCDC play a role in crime prevention. This signifies that people acknowledged the effort of NSCDC in crime prevention in Nigeria.

Similarly, in an interview with community leaders, they revealed that:

"NSCDC personnel play a significant role and are really trying their best in preventing crime in the society which makes them to be seen and recognized as agents of maintaining law and order in the community (IDI with community leaders, 2018)". 
International Journal of Trend in Scientific Research and Development (IJTSRD) @ www.ijtsrd.com eISSN: 2456-6470

Table 2: Roles of NSCDC in Crime Prevention

\begin{tabular}{|c|c|c|c|}
\hline $\begin{array}{c}\text { Roles of NSCDC in } \\
\text { Crime Prevention }\end{array}$ & Yes (\%) & No (\%) & $\begin{array}{c}\text { Total } \\
(\%)\end{array}$ \\
\hline Crime detection & $\begin{array}{c}66 \\
(86.8 \%)\end{array}$ & $\begin{array}{c}10 \\
(13.2 \%)\end{array}$ & $\begin{array}{c}76 \\
(100 \%)\end{array}$ \\
\hline $\begin{array}{c}\text { Apprehending } \\
\text { offenders }\end{array}$ & $\begin{array}{c}59 \\
(77.6 \%)\end{array}$ & $\begin{array}{c}17 \\
(22.4 \%)\end{array}$ & $\begin{array}{c}76 \\
(100 \%)\end{array}$ \\
\hline $\begin{array}{c}\text { Protection of lives } \\
\text { and properties }\end{array}$ & $\begin{array}{c}72 \\
(94.7 \%)\end{array}$ & $\begin{array}{c}4 \\
(5.3 \%)\end{array}$ & $\begin{array}{c}76 \\
(100 \%)\end{array}$ \\
\hline $\begin{array}{c}\text { Maintenance of law } \\
\text { and order }\end{array}$ & $\begin{array}{c}71 \\
(93.4 \%)\end{array}$ & $\begin{array}{c}5 \\
(6.6 \%)\end{array}$ & $\begin{array}{c}76 \\
(100 \%)\end{array}$ \\
\hline
\end{tabular}

Source, Field work, 2018

Table 2 presents the respondent's views on the roles of NSCDC in crime prevention. It revealed that majority of the respondents with $94.7 \%$ revealed that protection of lives and property is the major role of NSCDC in crime prevention while minority of the respondents are of the believed that apprehending offenders is the role of NSCDC in crime prevention in Nigeria.

Similarly, in an interview with NSCDC officials they revealed that:

"Protection of lives and property and maintenance of law and order are the significant roles of NSCDC in crime prevention as they are saddled with law enforcement responsibility (IDI with NSCDC Officials, 2018)".

Table 3: Satisfaction with the Role of NSCDC in Crime Prevention

\begin{tabular}{|c|c|c|}
\hline Responses & Frequency & Percentage \\
\hline Yes & 62 & 81.6 \\
\hline No & 14 & 18.4 \\
\hline Total & $\mathbf{7 6}$ & $\mathbf{1 0 0}$ \\
\hline
\end{tabular}

Source: Field work, 2018

Table 3 presents the respondent's views on their satisfaction with roles of NSCDC in crime prevention. It revealed that $81.6 \%$ of the respondents are satisfied with the role played by the NSCDC in crime prevention while the $18.4 \%$ are not satisfied with the role of NSCDC in crime prevention. This implies that majority of the respondents are satisfied with the roles of NSCDC in crime prevention and control.

In an interview with community leaders, they revealed that: "People are satisfied with the role played by the NSCDC in crime prevention and control as it helped in reducing crime in the community which makes the community a better place for living (IDI with community leaders, 2018)".

Table 4: Achievement Recorded by NSCDC in Crime Prevention

\begin{tabular}{|c|c|c|c|}
\hline $\begin{array}{c}\text { The achievement } \\
\text { recorded by NSCDC }\end{array}$ & Yes (\%) & No (\%) & $\begin{array}{c}\text { Total } \\
(\%)\end{array}$ \\
\hline Crime reduction & $\begin{array}{c}50 \\
(65.8 \%)\end{array}$ & $\begin{array}{c}26 \\
(34.2 \%)\end{array}$ & $\begin{array}{c}76 \\
(100 \%)\end{array}$ \\
\hline $\begin{array}{c}\text { Apprehending } \\
\text { suspects }\end{array}$ & $\begin{array}{c}72 \\
(94.7 \%)\end{array}$ & $4(5.3 \%)$ & $\begin{array}{c}76 \\
(100 \%)\end{array}$ \\
\hline $\begin{array}{c}\text { Providing safety in } \\
\text { the community }\end{array}$ & $\begin{array}{c}75 \\
(98.7 \%)\end{array}$ & $1(1.3 \%)$ & $\begin{array}{c}76 \\
(100 \%)\end{array}$ \\
\hline $\begin{array}{c}71 \\
\text { Prosecuting } \\
\text { offenders }\end{array}$ & $\begin{array}{c}71 \% \\
(93.4 \%)\end{array}$ & $5(6.6 \%)$ & $\begin{array}{c}76 \\
(100 \%)\end{array}$ \\
\hline
\end{tabular}

Source, Field work, 2018
Table 4 above presents the achievements of NSCDC in crime prevention where $98.7 \%$ of the respondents revealed that providing safety in the community is the major achievement of NSCDC while $65.8 \%$ of the respondents revealed that crime reduction is the achievement of NSCDC in crime prevention. This indicates that respondents believed that NSCDC has achieved in providing safety and reducing the rate of crime in Nigeria.

Table 5: Challenges Confronting NSCDC in Crime Prevention

\begin{tabular}{|c|c|c|c|}
\hline $\begin{array}{c}\text { Challenges } \\
\text { Confronting NSCDC }\end{array}$ & Yes & No & Total \\
\hline Lack of man power & $\begin{array}{c}76 \\
(100 \%)\end{array}$ & $\begin{array}{c}0 \\
(0.00 \%)\end{array}$ & $\begin{array}{c}76 \\
(100 \%)\end{array}$ \\
\hline Inadequate logistic & $\begin{array}{c}68 \\
(89.5 \%)\end{array}$ & $\begin{array}{c}8 \\
(10.5 \%)\end{array}$ & $\begin{array}{c}76 \\
(100 \%)\end{array}$ \\
\hline $\begin{array}{c}\text { Lack of adequate } \\
\text { welfare }\end{array}$ & $\begin{array}{c}60 \\
(78.9 \%)\end{array}$ & $\begin{array}{c}16 \\
(21.1 \%)\end{array}$ & $\begin{array}{c}76 \\
(100 \%)\end{array}$ \\
\hline $\begin{array}{c}\text { Inadequate training } \\
(52.6 \%)\end{array}$ & $\begin{array}{c}36 \\
(47.4 \%)\end{array}$ & $\begin{array}{c}76 \\
(100 \%)\end{array}$ \\
\hline
\end{tabular}

\section{Source: field work, 2018}

Table 5 above presents the challenges confronting NSCDC in crime prevention where all the respondents with $100 \%$ revealed that lack of manpower is the major challenge confronting NSCDC while $52.6 \%$ of the respondents revealed that inadequate training is the major challenge confronting NSCDC in crime prevention. This indicates that respondents revealed that lack of manpower and inadequate training are major challenges confronting NSCDC in crime prevention in Nigeria.

\section{CONCLUSION AND RECOMMENDATIONS}

Crime as one of the major social problems bedeviling Nigerian society necessitated the establishment of various law enforcement agencies including Nigerian Security and Civil Defense Corps (NSCDC). However, the paper concluded that NSCDC play many roles in the prevention of crime and thus people are satisfied with their roles in preventing crime in the society. In view of the finding, the paper recommends that:

1. Government should recruit more personnel to the NSCDC and the recruitment should be based on merit to avoid recruiting the bad eggs.

2. Government should support and encourage NSCDC by providing the agency with adequate logistics that will ensure effective crime prevention.

3. Government should increase the welfare of NSCDC personnel to enable them to work effectively without engaging in corruption and other financial crimes.

4. Government should enlighten the community members on the need to collaborate with security agencies particularly NSCDC to prevent and control crime in the society.

5. There is need for adequate training and improvement of personnel relations with the public to enhance mutual understanding between community members and NSCDC officers. 


\section{References}

[1] Abolurin, A. (2008). The role of Nigeria Security and Civil Defense Corps in Safeguarding Collective Security in Nigeria. Paper Presented at the National Conference of the Society for Peace Studies and Practice Unpublished Work.

[2] Adebayo A. A (2013).Social factors Affecting Effective Crime Prevention and Control in Nigeria. International journal of applied sociology. (pp 2-3).

[3] Berned O. and Olusegun A.J (2013).Traditional Values, Belief and Reliance on Indigenous

[4] Resources for Crime Control in Modern Southwest Nigeria: African Research review. An International Multidisciplinary Journal, 7(1), 2070-0083

[5] Blessing E.N. (2009).The Indispensable Role of Nigeria Security and Civil Defence Corp to Nigeria National Security: SBMTN Ekede Conference Journal. 1(1), 978288-45-0

[6] Dansabo S. (2014).The Role of Nigerian Security and Civil Defense Corps in Supplementing the

[7] Effort of Security Agencies: Project submitted to the Department of Public Administration College of Business and Management Studies, Jigawa State Polytechnic, Dutse.
[8] Madaki I. (2016). "The role of NSCDC in combating crime" a BSc project submitted to Department of sociology federal university Dutse.

[9] NSCDC ACT (2007).The laws of the federal republic of Nigeria.

[10] Phenson A. (2014).the Nigerian State, Security Management Mandate and Challenges in the NigerDelta Region, Nigeria: Journal of Research \& Method in Education 4(1), 2320-7388,

[11] Uzondu J. (2012). Civil Defense: The Challenge Of Bearing Arms: Retrieved on 20/11/2015 Fromhttp://en.wikipedia.org/wiki/Civil defence at 9:00 pm

[12] Eric A. and Oluwagbenga (2017). Oil theft, illegal bunkering, and pipeline vandalism: its Impacts on Nigerian economy, 2015 to 2016.

[13] Maguire M., Morgan R. and Reiner R. (1997) (eds). The oxford handbook of criminology. Oxford University Press.

[14] Murphy, J. G (1985) "Retributivism, moral education and the liberal state", criminal justice Ethics, 4:311.

[15] United Nations Office on Drug and Centre (2014). United Nations standard and norms in culture Prevention at your fingertips. 